\title{
Keanekaragaman Spesies Herpetofauna Pada Berbagai Tipe Tutupan Lahan Di Lansekap Perkebunan Sawit: Studi Kasus di PT. BLP Central Borneo
}

\section{Diversity of Herpetofauna In Various Types of Land Cover of Oil Palm Landscape: A Case Study in PT. BLP, Central Borneo}

Rozza Tri Kwatrina ${ }^{a}$, Yanto Santosa ${ }^{b}$, Panji Maulana ${ }^{c}$

${ }^{a}$ Program Pascasarjana, Program Studi Konservasi Biodiversitas Tropika, Fakultas Kehutanan, Institut Pertanian Bogor, Kampus IPB Darmaga, Bogor, 16680, Indonesia

${ }^{\mathrm{b}}$ Departemen Konservasi Sumber Daya Hutan, Fakultas Kehutanan, Institut Pertanian Bogor, Kampus IPB Darmaga, Bogor, 16680, Indonesia

${ }^{c}$ Program Sarjana, Program Studi Konservasi Sumberdaya Hutan dan Ekowisata, Fakultas Kehutanan, Institut Pertanian Bogor, Kampus IPB Darmaga, Bogor, 16680, Indonesia

\section{Article Info:}

Received: 02 - 04 - 2018

Accepted: 05 - 09 - 2018

Keywords:

Perkebunan kelapa sawit, amphibi, reptilia, indeks

keanekaragaman spesies, Kalimantan Tengah.

Corresponding Author: Rozza Tri Kwatrina Manajemen Sumberdaya Pantai, Program Studi Konservasi Biodiversitas Tropika, Fakultas Kehutanan, Institut Pertanian Bogor, Kampus IPB Darmaga, Indonesia;

Email: rozzatk@yahoo.com
Abstract: The expansion of oil palm plantations in Indonesia is often blamed for triggering the destruction of natural resources and reducing tropical biodiversity. Herpetofauna is one of biodiversity in oil palm plantations, and information about its species diversity is lim-ited. This study aims to reveal the diversity of Herpetofauna diversity in the oil palm landscape in Central Kalimantan. Field inven-tories were conducted on seven types of land cover: young palm, mature palm oil, old palm oil, High Conservation Value areas, secondary forests, shrubs and smallholder plantations. We used the Visual Encounter Method to find Herpetofauna species in all land cover types. This study revealed that the diversity of Herpetofauna species in PT BLP varies based on the type of land cover. The HCV area and Secondary Forest have the largest number of species (12 species), while secondary Forest has the highest abundance among other types of land cover, followed by old oil palm plantations. The Oil palm plantation landscapes with land cover variations, water availability, and riparian areas can be part of the habitat of several Herpetofauna species and are man-aged for sustainable palm oil management schemes.

How to cite (CSE Style $8^{\text {th }}$ Edition):

Kwatrina RT, Santosa Y, Maulana P. 2019. Keanekaragaman Spesies Herpetofauna pada Berbagai Tipe Tutupan Lahan di Lansekap Perkebunan Sawit: Studi Kasus di PT. BLP Central Borneo. JPSL 9(2): 304-313. http://dx.doi.org/10.29244/jps1.9.2.304-313.

\section{PENDAHULUAN}

\section{Latar Belakang}

Kelapa sawit (Elaeis guineensis) merupakan tanaman penghasil minyak nabati yang memiliki nilai ekonomis tinggi dan berkontribusi besar bagi perekonomian Indonesia. Sejak beberapa dekade terakhir, produksi Crude Palm Oil (CPO) Indonesia meningkat dari 2658 juta ton pada tahun 1991 menjadi 35.3 juta ton pada tahun 2017 (Dirjenbun 2016). Kondisi ini membuat komoditas kelapa sawit sebagai sumber devisa terbesar dari sektor perkebunan dalam perdagangan Indonesia, dan menempatkan Indonesia sebagai eksportir minyak sawit terbesar di dunia. 
Tingginya permintaan CPO dunia mendorong ekspansi perkebunan kelapa sawit di wilayah tropis, termasuk Indonesia. Pada tahun 2017, luas areal perkebunan mencapai 12,3 juta hektar (Dirjenbun 2016). Namun demikian, pembukaan lahan untuk perluasan areal perkebunan tersebut menimbulkan kekhawatiran global terhadap kerusakan sumber daya alam, lingkungan, dan keanekaragaman hayati (Fitzherbert et al. 2008, Koh dan Wilcove 2008). Herpetofauna adalah salah satu keanekaragaman hayati yang rentan terhadap pembukaan perkebunan sawit (Alford dan Richards 1999), sedangkan perannya dalam kosistem sangat penting. Herpetofauna memiliki peran dalam jaring-jaring makanan sebagai konsumen, predator, mangsa, serta bio-indikator kondisi lingkungan (Hocking and Babbit 2014, Stuebbin dan Cohen 1997).

Salah satu ancaman terhadap herpetofauna adalah hilangnya habitat untuk areal pertanian dan perkebunan, serta berbagai aktivitas manusia yang berdampak menurunkan kualitas habitat dan konektivitas lanskap (Urbina-Cardona, 2008). Peningkatan fragmentasi habitat berkorelasi terhadap perubahan kondisi lingkungan seperti suhu dan kelembaban dan membuat banyak spesies lebih rentan terhadap penurunan populasi, termasuk Herpetofauna (Lehtinen et al. 2003, Lehtinen dan Ramanamanjato 2006, Muslim 2017). Beberapa penelitian menunjukkan adanya dampak dari perubahan hutan terhadap komunitas herpetofauna tropis (Vitt dan Caldwell 2001, Wanger et al. 2010). Dengan demikian, konservasi hutan merupakan salah satu upaya pengelolaan lingkungan yang harus dilakukan oleh perkebunan berskala besar (Dewani et al. 2014, Septiawan et al. 2014) untuk mendukung sustainable oil palm management. Pengelolaan lansekap perkebunan sawit yang berkelanjutan, harus didukung oleh data ilmiah yang memadai. Namun demikian, terkait dengan Herpetofauna, informasi yang tersedia mengenai keanekaragaman spesies pada lansekap perkebunan sawit di Indonesia masih sangat terbatas. Beberapa penelitian yang pernah dilakukan diantaranya berlokasi di wilayah Neotropik (Gallmetzer dan Schulze 2015), dan Malaysia (Faruk et al. 2013, Gillespie et al. 2012). Oleh sebab itu, penelitian ini bertujuan untuk mengetahui variasi keanekaragaman spesies Herpetofauna pada berbagai tipe tutupan lahan di lansekap perkebunan sawit di Indonesia, khususnya Kalimantan Tengah sebagai dasar ilmiah dalam konservasi spesies Herpetofauna.

\section{Metode}

\section{Waktu dan Tempat}

Penelitian dilaksanakan pada bulan Agustus 2017 di PT. BLP yang terletak di Kabupaten Kotawaringin Barat, Propinsi Kalimantan Tengah. Pengambilan data dilakukan pada tujuh tipe tutupan lahan yang terdapat pada areal perkebunan sawit dan wilayah di sekitarnya yaitu sawit muda/ SM,(tegakan tanaman sawit berumur lima tahun), sawit sedang/SS (tegakan tanaman sawit berumur 11 tahun), sawit tua/ST (tegakan tanaman sawit berumur 20 tahun), kebun rakyat (KR), area Nilai Konservasi Tinggi (NKT), hutan sekunder (HS), dan semak belukar (SB).

\section{Alat}

Alat yang digunakan dalam penelitian ini adalah buku panduan identifikasi herpetofauna, kamera DSLR, jam tangan, GPS (Global Positioning System), tallysheet dan alat tulis, headlamp, termometer, plastik spesimen, spidol permanen, karung dan tali tambang serta hook (tongkat ular).

\section{Pengumpulan Data}

Pengumpulan data keanakeragaman spesies Herpetofauna dilakukan dengan menggunakan metode Visual Encounter Survey (VES) with transect design (Heyer et al. 1994). Pada tipe setiap tutupan lahan dibuat satu jalur pengamatan sepanjang satu kilometer. Pengamatan dilakukan secara simultan pada seluruh tipe habitat dengan cara berjalan menyusuri jalur yang sudah ditentukan pada malam harisaat jam aktif Amfibi, sekitar pukul 19.00-21.00 WIB. Secara serentak, dua orang pengamat berjalan dan melakukan pencarian di sepanjang jalur pada masing-masing tipe tutupan lahan dan mencatat spesies, jumlah herpetofauna yang terlihat, waktu perjumpaan, dan substrat dimana Herpetofauna ditemukan. Sehingga, 
pada saat jam pengamatan, terdapat tujuh tim yang melakukan pengamatan pada waktu bersamaan. Pengamatan dilakukan sebanyak tiga kali ulangan. Untuk individu Herpetofauna yang belum teridentifikasi, dilakukan penangkapan untuk identifikasi lebih lanjut menggunakan acuan Inger dan Stuebbing (1997), Iskandar dan Enderlen (2006), dan Mistar (2008), serta penamaan jenis mengacu pada Frost (2012).

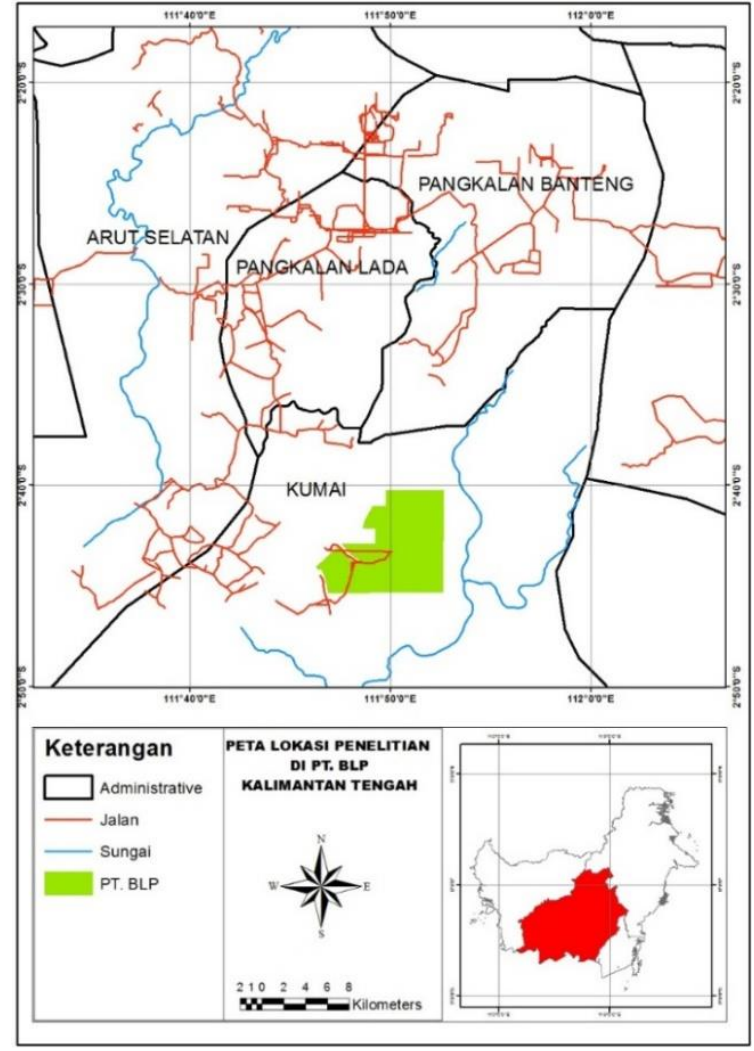

Gambar 1. Peta lokasi penelitian di areal perkebunan PT.BLP dan sekitarnya

\section{Analisis Data}

Data dianalisis menggunakan indeks-indeks sebagai berikut:

\section{Indeks kekayaan Margalef (Dmg)}

Indeks kekayaan spesies (species richness) berfungsi untuk mengetahui kekayaan spesies setiap spesies dalam setiap komunitas yang dijumpai. Rumus yang digunakan sebagai berikut (Magurran 1988):

$$
\operatorname{Dmg}=\frac{\mathrm{s}-1}{\ln (\mathrm{N})}
$$

Keterangan: Dmg = Indeks kekayaan spesies; $\mathrm{S}=$ Jumlah spesies; $\mathrm{N}=$ Total jumlah individu seluruh spesies

\section{Indeks kemerataan spesies(E)}

Indeks kemerataan/Index of Evenness (Magurran 1988) berfungsi untuk mengetahui kemerataan setiap spesies dalam setiap komunitas yang dijumpai.

$$
\mathrm{E}=\frac{H^{\prime}}{\ln \mathrm{S}}
$$

Keterangan: E = Indeks kemerataan spesies; H'= Indeks Shannon-Wiener; S = Jumlah spesies

\section{Indeks kesamaan komunitas herpetofauna}

Kesamaan antara dua tipe habitat dihitung dengan menggunakan indeks kesamaan spesies Sorensen (Magurran 1988):

$$
\mathrm{IS}=\frac{2 c}{\mathrm{a}+\mathrm{b}}
$$


Keterangan: $\mathrm{a}=$ Jumlah spesies yang terdapat di komunitas $\mathrm{A} ; \mathrm{b}=$ Jumlah spesies yang terdapat di komunitas B; c = Jumlah spesies yang ditemukan di komunitas A dan B.

\section{HASIL DAN PEMBAHASAN}

\section{Variasi keanekaragaman spesies herpetofauna}

Berdasarkan hasil pengamatan pada tujuh tipe tutupan lahan, ditemukan sebanyak 17 spesies Herpetofauna yang tergolong pada 10 famili dan 159 individu (9 spesies Amfibi dari 4 famili, dan 8 Reptil dari 6 famili.

Empat famili Amfibi yang ditemukan dalam penelitian ini adalah Bufonidae (1), Dicroglossidae (3), Randiae (3), dan Rhacoporidae (2), sedangkan untuk Reptilia ditemukan sebanyak 6 famili yaitu Geckonidae (1), Scincidae (3), Lacertidae (1), Colubridae (1), Pythonidae (1), Varanidae (1) (Tabel 1).

Tabel 1 Spesies herpetofauna yang ditemukan pada berbagai tipe tutupan lahan di PT. BLP

\begin{tabular}{|c|c|c|c|c|c|c|c|c|c|}
\hline \multirow[b]{2}{*}{ No. } & \multirow[b]{2}{*}{ Famili/Spesies } & \multicolumn{8}{|c|}{ Tipe tutupan lahan } \\
\hline & & SM & $\begin{array}{l}\mathbf{S} \\
\mathbf{S}\end{array}$ & $\begin{array}{l}\mathbf{S} \\
\mathbf{T}\end{array}$ & $\begin{array}{l}\mathbf{K} \\
\mathbf{R}\end{array}$ & NKT & $\begin{array}{l}\mathbf{H} \\
\mathbf{S}\end{array}$ & $\begin{array}{l}\mathbf{S} \\
\mathbf{B}\end{array}$ & Total \\
\hline \multicolumn{10}{|c|}{ AMFIBI } \\
\hline \multicolumn{10}{|c|}{ Bufonidae } \\
\hline 1 & Ingerophrynus iporcatus & 3 & 2 & 2 & 2 & 0 & 1 & 2 & 12 \\
\hline \multicolumn{10}{|c|}{ Dicroglossidae } \\
\hline 2 & Fejervarya cancrivora & 8 & 8 & 2 & 1 & 0 & 1 & 0 & 20 \\
\hline 3 & Fejervarya limnocharis & 2 & 2 & 3 & 0 & 0 & 5 & 0 & 12 \\
\hline 4 & Limnonectes sp. & 2 & 1 & 1 & 6 & 5 & 3 & 0 & 18 \\
\hline \multicolumn{10}{|c|}{ Ranidae } \\
\hline 5 & Pulchrana baramica & 10 & 7 & 5 & 3 & 5 & 1 & 1 & 32 \\
\hline 6 & Hylarana erythraae & 3 & 2 & 2 & 1 & 9 & 0 & 0 & 17 \\
\hline 7 & Amnirana nicobariensis & 0 & 1 & 0 & 0 & 2 & 0 & 0 & 3 \\
\hline \multicolumn{10}{|c|}{ Rhacoporidae } \\
\hline 8 & Polypedatesleucomystax & 1 & 2 & 1 & 0 & 5 & 2 & 1 & 12 \\
\hline 9 & Polypedates macrotis & 0 & 0 & 0 & 1 & 2 & 1 & 0 & 4 \\
\hline \multicolumn{10}{|c|}{ REPTIL } \\
\hline \multicolumn{10}{|c|}{ Geckonidae } \\
\hline 10 & Hemidactylus frenatus & 0 & 2 & 1 & 1 & 3 & 0 & 0 & 7 \\
\hline \multicolumn{10}{|c|}{ Scincidae } \\
\hline 11 & Eutropis multifasciata & 1 & 0 & 1 & 0 & 1 & 2 & 1 & 6 \\
\hline 12 & Eutropis rudis & 1 & 1 & 1 & 0 & 2 & 2 & 1 & 8 \\
\hline 13 & Dasia vittata & 0 & 0 & 0 & 0 & 0 & 1 & 0 & 1 \\
\hline \multicolumn{10}{|c|}{ Lacertidae } \\
\hline 14 & Takydromus sexlineatus & 0 & 0 & 0 & 0 & 1 & 0 & 0 & 1 \\
\hline \multicolumn{10}{|c|}{ Colubridae } \\
\hline 15 & Pseudorabdion albonuchalis & 0 & 0 & 0 & 0 & 0 & 1 & 0 & 1 \\
\hline \multicolumn{10}{|c|}{ Pythonidae } \\
\hline 16 & Malayopython reticulatus & 0 & 0 & 0 & 0 & 1 & 0 & 0 & 1 \\
\hline \multicolumn{10}{|c|}{ Varanidae } \\
\hline 17 & Varanus salvator & 0 & 0 & 1 & 0 & 1 & 1 & 1 & 4 \\
\hline & Total Individu & 31 & 28 & 20 & 15 & 37 & 21 & 7 & 159 \\
\hline & Total spesies/ jalur & 9 & 10 & 11 & 7 & 12 & 12 & 6 & 17 \\
\hline
\end{tabular}

Keterangan =SM: Sawit Muda; SS; Sawit Sedang: ST; Sawit Tua; KR; Kebun Rakyat; NKT; Nilai Konservasi Tinggi; HS: Hutan Sekunder; SB:Semak Belukar 
Famili Ranidae dan Dicroglossidae merupakan famili Amfibi dengan anggota paling banyak ditemukan pada semua lokasi yaitu masing-masing sebanyak 3 spesies. Hal ini dipengaruhi oleh tingginya daya adaptabilitas spesies dari kedua family tersebut, sehingga dapat hidup pada berbagai habitat bahkan habitat yang terganggu. Selain itu, famili Ranidae merupakan salah satu famili dengan penyebaran paling luas di Indonesia (Iskandar 1998, Irham et al. 2012). Famili Scincidae merupakan famili Reptil dengan jumlah spesies terbanyak (3 spesies), yaitu Eutropis multifasciata, Eutropis rudis, Dasia vittata. Famili ini merupakan famili Reptilia terbesar dari 16 famili kadal (Hutchinson 1993).

Spesies Amfibi dan Reptil yang paling banyak ditemukan dalam penelitian ini adalah masing-masing Pulchrana baramica sebanyak 32 individu dan Eutrophis rudis sebanyak 8 spesies. Pulchrana baramica diketahui dapat ditemukan di hutan dataran rendah termasuk hutan rawa gambut, hutan primer dataran, dan hutan rawa. Spesies ini berkembang biak di air (Stuebbing et al. 2017). Selain itu anggota family Ranidae yang juga banyak ditemukan adalah Hylarana erithraea sebanyak 17 individu. Spesies ini umum ditemukan pada habitat dalam genangan air, danau, telaga, sawah, dan pada dataran yang rendah (biasanya kurang dari $250 \mathrm{~m} \mathrm{dpl}$ ), walaupun juga dapat hidup di hutan sekunder, kebun sawit, bekas tambang, atau pada ketinggian mencapai $1100 \mathrm{~m}$ dpl. (Iskandar 1998, Darmawan 2008). Eutrophis rudis banyak ditemukan sedang berjemur di atas serasah dan kayu lapuk. Menurut Barley (2014), genus Eutrophis memiliki kepadatan yang cukup tinggi, rentang habitat yang luas, dan kemampuan adaptasi yang cukup tinggi sehingga dapat ditemukan pada berbagai ketinggian dan kondisi habitat yang berbeda.

Spesies Amfibi dan Reptil yang ditemukan pada penelitian ini sebagian besar termasuk spesies-spesies toleran yang memiliki daya adaptasi tinggi seperti Ingerophrynus biporcatus, Fejervarya cancrivora, Fejervarya limnocharis, Limnonectes sp., Pulchrana baramica, Hylarana erythrae, Amnirana nicobariensis, Polypedates leucomystax, dan Polypedates macrotis. Hasil ini sejalan dengan hasil penelitian Gallmetzher (2014) dan Kurz et al. (2016), yang menemukan spesies-spesies yang toleran terhadap gangguan lingkungan. Gillespie et al. (2012) menyatakan bahwa perkebunan kelapa sawit tampaknya menarik spesies yang toleran terhadap gangguan.

Selain spesies toleran, pada penelitian ini juga ditemukan beberapa spesies yang memerlukan pohon seperti Polypedates leucomystax, Polypedates macrotis, Dasia vittata, Takydromus sexlineatus. Walaupun dapat dijumpai di areal perkebunan, namun sebagian besar spesies tersebut lebih banyak ditemukan pada areal NKT dan hutan sekunder. Bahkan Takydromus sexlineatus, Pseudorabdion albonuchalis, dan Malayopython reticulatus hanya ditemukan pada area NKT dan hutan sekunder. Dasia vittata, selain sebagai spesies arboreal, juga merupakan spesies endemik Kalimantan yang dikenal dengan Borneo skink sebagaimana dicantumkan dalam The Reptile Database.

Areal NKT dan Hutan sekunder memiliki jumlah spesies terbanyak, yaitu masing-masing 12 spesies, sedangkan semak belukar merupakan tipe tutupan lahan yang paling sedikit ditemukan Herpetofauna yaitu 6 spesies. Pada areal perkebunan sawit, jumlah spesies Herpetofauna cenderung bertambah seiring dengan bertambahnya klas umur tanaman sawit. Namun sebaliknya, jumlah individu cenderung menurun seiring bertambahnya klas umur tanaman sawit. Pada kebun Sawit Muda (SM) ditemukan sebanyak 9 spesies dengan 31 individu, pada sawit sedang ditemukan sebanyak 10 spesies dengan 28 individu, dan pada kebun sawit tua ditemukan sebanyak 11 spesies dengan 20 individu.

Tingginya jumlah spesies pada areal hutan sekunder dan areal NKT dapat disebabkan oleh kondisi hutan yang memiliki tutupan tajuk yang rapat dengan multi strata, serta banyaknya serasah-serasah dari daun dan pohon lapuk. Sedangkan rendahnya jumlah spesies Herpetofauna pada area semak belukar diantara tipe tutupan lahan lainnya dipengaruhi oleh tutupan tajuk pada semak belukar yang relatif terbuka karena sedikitnya kanopi dari pohon dan tiang. Menurut Meijaard et al. (2006) kanopi yang terbuka dapat memengaruhi perubahan intensitas, cahaya, konduktivitas dan $\mathrm{pH}$ aliran air, suhu udara, kelembaban dan distribusi serasah daun. Menurut Luskin dan Potts (2011) kurangnya kompleksitas struktural vegetasi dan tutupan kanopi dapat menurunkan kelembaban dan peningkatan fluktuasi suhu antara siang dan malam.

Selain tutupan tajuk, air merupakan faktor pembatas bagi Herpetofauna. Amfibi khususnya, biasanya hidup di areal berhutan atau area lainnya yang dekat dengan air, bahkan beberapa spesies sangat tergantung 
pada keberadaan air pada seluruh tahapan hidupnya (Iskandar 1998, Yanuarefa et al. 2012). Amfibi memerlukan air untuk bertelur dan berkembang serta menjaga diri tetap lembab. Odum (1971) menyatakan bahwa pada habitat terestrial, air merupakan faktor pembatas bagi hewan darat yang tidak mampu memperoleh air dengan mudah seperti hewan air. Pada hutan sekunder terdapat sungai kecil dan kanal di pinggir hutan, demikian juga pada areal NKT yang terdapat aliran sungai dan danau kecil. Keberadaan air ini diduga merupakan salah satu faktor yang mempengaruhi kehadiran dan tingginya jumlah spesies pada kedua tipe habitat tersebut.

\section{Variasi kekayaan dan kemerataan spesies herpetofauna}

Hutan sekunder merupakan tipe tutupan lahan dengan nilai indeks kekayaan Herpetofauna tertinggi yaitu 3.6, diikuti oleh sawit tua sebesar 3.34, dan NKT sebesar 3.05. Kebun sawit rakyat merupakan tipe habitat yang memiliki nilai indeks kekayaan Herpetofauna terkecil yaitu 2.22. Berdasarkan nilai indeks kemerataan, semak belukar memiliki kemerataan yang paling tinggi dibandingkan dengan tipe tutupan lahan lain yaitu sebesar 0.98 , sedangkan kebun sawit termuda memiliki kemerataan terendah yaitu sebesar 0.84 (Gambar 2).

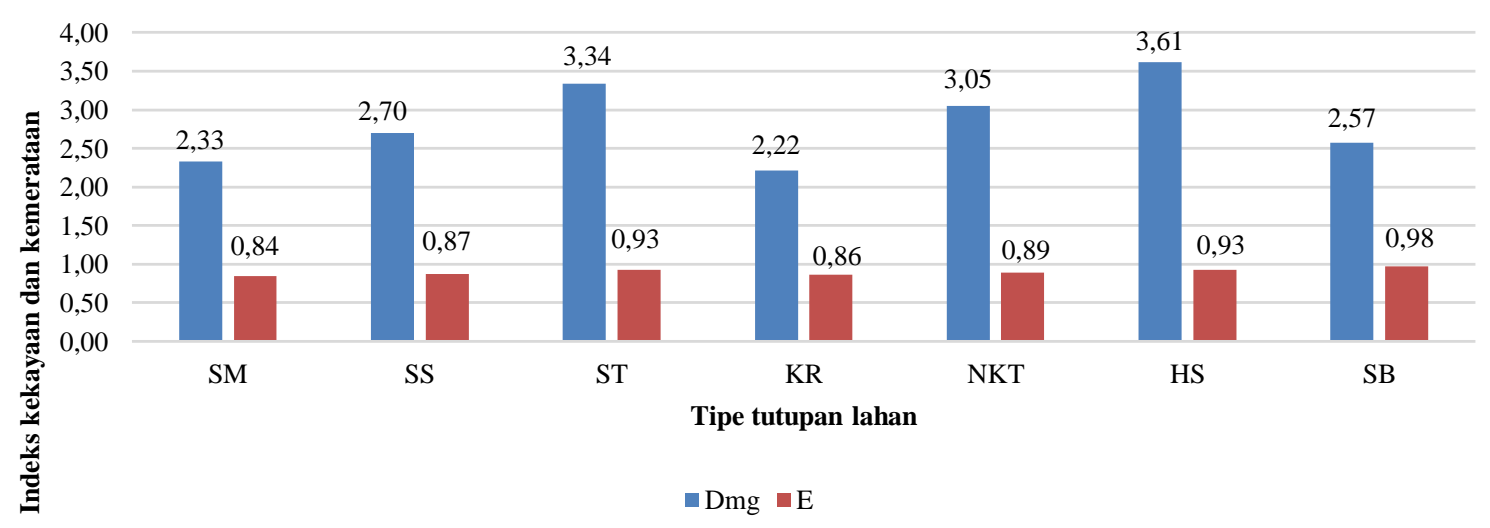

Gambar 2 Indeks kekayaan dan kemerataan spesies herpetofauna pada berbagai tipe tutupan lahan di PT $B L P$, Kalimantan Tengah

Tingginya tingkat kekayaan spesies pada hutan sekunder dapat dipengaruhi oleh tingginya jumlah spesies dan jumlah individu pada hutan sekunder. Hal ini dapat disebabkan oleh kondisi tutupan lahan yang lebih rapat dibandingkan dengan jalur lainnya, dan beragamnya komposisi mikrohabitat seperti serasah, pohon tumbang, semak, aliran sungai/kolam/kanal menyebabkan banyaknya spesies yang ditemukan pada lokasi hutan sekunder, area NKT, dan kebun sawit tua. Kusrini (2009) menyatakan kekayaan spesies dapat meningkat dengan semakin beragamnya habitat.

Nilai kemerataan spesies Herpetofauna dapat digunakan untuk membandingkan distribusi jumlah individu tiap spesies pada habitat tertentu. Nilai indeks kemerataan pada semua tipe tutupan lahan tergolong tinggi yaitu berkisar dari 0.84- 0.98. Semak belukar memiliki kemerataan yang paling tinggi dibandingkan dengan tipe tutupan lahan lainnya yaitu sebasar 0.98 , sedangkan sawit muda memiliki kemerataan terendah yaitu sebesar 0.84. Hal tersebut menunjukkan semua tipe tutupan lahan ini memiliki distribusi jumlah individu setiap spesies yang merata atau tidak adanya spesies yang dominan. Nilai kemerataan dapat digunakan sebagai indikator ada atau tidaknya spesies yang mendominasi pada suatu komunitas atau setiap spesies memiliki sebaran individu yang relatif sama atau stabil (Mac Arthur 1972, Santosa 1995).

Hasil penelitian ini menunjukkan bahwa semakin tua umur tanaman sawit maka semakin tinggi jumlah spesies dan kekayaan spesies Herpetofauna yang ditemukan, sedangkan distribusi spesies dalam komunitas semakin merata. Tingginya jumlah spesies pada kebun sawit tua dapat disebabkan oleh tutupan tajuk yang lebih rapat dibandingkan dengan sawit sedang dan sawit muda. Luasan daun pada tajuk kelapa sawit 
cenderung semakin meningkat dengan bertambahnya umur lebih lanjut dia menyimpulkan bahwa suhu dibawah kanopi kelapa sawit berumur 10 tahun lebih rendah dibandingkan kelapa sawit berumur 2 dan 4 tahun (Afandi 2014). Hal tersebut mempengaruhi suhu dan kelembaban di lantai kebun. Hasil pengukuran suhu pada saat pengamatan di setiap tipe tutupan lahan menunjukkan angka yang tidak jauh berbeda antara hutan sekunder, areal NKT, serta kebun sawit tua yaitu pada kisaran $24-25^{\circ} \mathrm{C}$. Suhu pada tipe tutupan lahan lainnya cenderung lebih tinggi, seperti pada kebun sawit muda dan sawit rakyat yang mencapai 26 $0 \mathrm{C}$.

Hasil penelitian ini sejalan dengan hasil penelitian Kurz et al. (2016) yang menemukan jumlah dan kekayaan/kekayaan spesies Amfibi pada kebun sawit yang telah menghasilkan (umur $>20$ tahun) lebih tinggi dibanding kebun sawit belum menghasilkan (umur $<3$ tahun). Kurz et al. (2016) menyatakan bahwa kanopi yang terbuka menghasilkan ketidakstabilan suhu yang berdampak pada sulitnya Amfibi untuk berkoloni, bertahan, dan bereproduksi.

\section{Variasi komposisi spesies herpetofauna}

Hasil penelitian menunjukkan kebun sawit tua dan kebun sawit muda memiliki komposisi spesies yang hampir sama (IS $=0.90)$, diikuti oleh kebun sawit sedang dan kebun sawit tua $(I S=0.86)$, serta sawit sedang dan sa000wit muda (IS $=0.84)($ Tabel 2).

Tabel 2 Nilai indeks kesamaan komunitas Herpetofauna pada berbagai tipe tutupan lahan di PT BLP, Kalimantan Tengah

\begin{tabular}{llllllll}
\hline Tipe tutupan lahan & $\begin{array}{l}\text { Sawit } \\
\text { muda }\end{array}$ & $\begin{array}{l}\text { Sawit } \\
\text { sedang }\end{array}$ & Sawit tua & $\begin{array}{l}\text { Kebun } \\
\text { rakyat }\end{array}$ & NKT & $\begin{array}{l}\text { Hutan } \\
\text { sekunder }\end{array}$ & $\begin{array}{l}\text { Semak } \\
\text { belukar }\end{array}$ \\
\hline Sawit muda & - & 0.84 & 0.90 & 0.63 & 0.57 & 0.76 & 0.67 \\
Sawit sedang & & - & 0.86 & 0.71 & 0.64 & 0.64 & 0.50 \\
Sawit tua & & & - & 0.67 & 0.70 & 0.78 & 0.71 \\
Kebun rakyat & & & & - & 0.53 & 0.53 & 0.31 \\
NKT & & & & - & 0.58 & 0.56 \\
Hutan sekunder & & & & & - & 0.67 \\
Semak belukar & & & & & & & - \\
\hline
\end{tabular}

Tipe tutupan lahan dengan nilai kesamaan spesies tertinggi adalah antara kebun sawit tertua dan kebun sawit termuda yaitu sebesar 0.90. Hal ini menunjukkan komposisi spesies yang terdapat di kedua tipe tutupan memiliki tingkat kesamaan yang tinggi. Tingginya nilai kemerataan ini disebabkan oleh beberapa faktor salah satunya adalah karena habitat yang berdekatan. Dari 10 spesies yang ditemukan pada kebun sawit sedang dan 11 spesies pada kebun sawit tertua terdapat 9 spesies yang terdapat di kedua lokasi yaitu yaitu Ingerophrynus biporcatus, Fejervarya cancrivora, Fejervarya limnocharis, Limnonectes sp., Hylarana baramica, Hylarana erythrae, Polypedates leucomystax, Hemidactylus frenatus, dan Eutrophis rudis. Kesamaan komunitas dapat terbentuk oleh beberapa faktor lingkungan seperti jarak antar habitat yang berdekatan (Kendeigh 1980) serta komposisi vegetasi yang sama (Mawazin dan Atok 2013).

Secara keseluruhan, hasil penelitian ini sejalan dengan hasil penelitian Gillespie et al. (2012) dalam aspek tingkat keanekaragaman spesies, dimana tingkat keanekaragaman spesies pada hutan sekunder lebih tinggi dibanding perkebunan. Walaupun dalam penelitian ini tingkat keanekaragaman spesies pada kebun sawit tua dan area NKT yang ada di dalam area perkebunan juga cukup tinggi, namun tetap berada di bawah tingkat keanekaragaman spesies pada hutan sekunder. Akan tetapi, hasil penelitian ini berbeda dengan hasil penelitian Faruk et al. (2013) yang menemukan tingkat keanekaragaman spesies antara hutan sekunder dan perkebunan sawit relatif sama. Perbedaan ini dapat disebabkan oleh perbedaan lokasi penelitian dan metode dan teknik pengumpulan data yang digunakan. Dalam penelitian ini pengamatan hanya dilakukan pada 
malam hari, sehingga terdapat kemungkinan beberapa spesies Reptilia yang aktif di pagi hari tidak dapat teramati dan mempengaruhi tingkat keanekaragaman yang diperoleh.

Konservasi spesies satwaliar sebagai sumber daya alam hayati pada habitat termodifikasi seperti pertanian dan perkebunan membutuhkan pengelolaan yang mampu mengakomodir pemanfaatan sekaligus pelestarian alam. Hasil penelitian ini menunjukkan bahwa keragaman tipe habitat pada areal perkebunan sawit dan sekitarnya mempengaruhi keanekaragaman spesies Herpetofauna. Keberadaan hutan sekunder di sekitar areal perkebunan, areal NKT dan kebun sawit tua di dalam areal perkebunanserta sumber air di dalamnya berkontribusi dalam menyediakan komponen habitat yang dibutuhkan oleh spesies-spesies Herpetofauna. Selain itu, variasi kelas umur tanaman sawit (muda, sawit, tua) perlu dipertahankan dan diatur dalam pengelolaan rotasi tanam karena dapat mempengaruhi jumlah, kekayaan, dan kemerataan spesies Herpetofauna. Faruk et al. 2013 menyatakan bahwa jika areal perkebunan sawit dapat dikelola dengan mempertahankan area penyangga riparian bersama-sama dengan area teresterial, maka spesiesspesies yang tergantung keberadaan hutan dapat dipertahankan di dalam lansekap perkebunan sawit. Oleh sebab itu, selain mempertahankan keanekaragaman tipe tutupan lahan, juga diperlukan area riparian yang bersumber dari sempadan sungai maupun kanal yang dibangun di dalam lansekap perkebunan sawit. Semuanya dapat dikelola sebagai suatu ekosistemyang mendukung kelangsungan hidup spesies Herpetofauna, dan keberlanjutan nilai ekologis pada lansekap perkebunan sawit.

\section{KESIMPULAN}

Variasi tipe tutupan lahan memberikan respon yang berbeda terhadap tingkat keanekaragaman spesies Herpetofauna di perkebunan sawit. Tipe tutupan lahan NKT dan Hutan Sekunder memiliki jumlah spesies terbesar yaitu masing-masing 12 spesies, sedangkan Hutan Sekunder merupakan tipe tutupan lahan dengan kekayaan tertinggi diantara tipe tutupan lahan lainnya. Lansekap perkebunan sawit yang memiliki beberapa tipe tutupan lahan, ketersediaan air, atau area riparian, dapat membentuk mikrohabitat yang sesuai dan menjadi bagian habitat bagi beberapa spesies Herpetofauna.

\section{UCAPAN TERIMA KASIH}

Ucapan terima kasih disampaikan kepada PT. BLP atas izin penggunaan lokasi dan bantuan yang diberikan selama kegiatan di lapangan.

\section{DAFTAR PUSTAKA}

[Dirjenbun] Direktorat Jendral Perkebunan. 2016. Statistik Perkebunan Indonesia 2015-2017: Kelapa Sawit. [terhubung berkala]. http://dirjenbun.pertanian.go.id. [21 November 2017].

Afandi AB. 2014. Karakteristik radiasi matahari pertanaman kelapa sawit (implikasinya terhadap iklim mikro dan potensi tanaman sela). Skripsi. Bogor: Fakultas Matematika dan IPA, Institut Pertanian Bogor.

Alford RA, and Richards SJ. 1999. Global amphibian declines: a problem in applied ecology. Annual Review of Ecology and Systematics. 30:133-165.

Barley AJ. 2014. From Microevolutionary Processes to Macroevolutionary Patterns: Investigating Diversification at Multiple Scales In Southeast Asian Lizards. Disertasi. USA: University of Kansas.

Darmawan B. 2008. Keanekaragaman amfibi di berbagai tipe habitat: studi kasus di eks-HPH PT Rimba Karya Indah Kabupaten Bungo, Provinsi Jambi. Skripsi. Bogor: Fakultas Kehutanan, Institut pertanian.

Dewani AP, Boer R, Jannah N. 2014. Analisis jejak karbon agribisnis untuk menyusun arahan strategi dan Program Corporate Social Responsibility (CSR). Jurnal Penelitian Sumber Daya Alam dan 
Lingkungan. 4(1):96-104.

Faruk A, Belabut D, Ahmad N, Knell RJ, Garner TWJ. 2013. Effects of oil-palm plantations on diversity of tropical anurans. Conservation Biology. 27:615-624.

Fitzherbert EB, Struebig MJ, Morel A, Danielsen F, Brulh CA, Donald PA, Phalan B. 2008. How will oil palm expansion affect biodiversity?. Trends in Ecology and Evolution. 23:538-545.

Frost DR. 2012. Amphibian Species of the world: An online Reference. Version 5.6. Electronic database accessible at http://research.amnh.org/hepetology/amphibian/index.php.

Gallmetzer N, Schulze CH. 2015. Impact of oil palm agriculture on understory amphibians and reptiles: A Mesoamerican perspective. Global Ecology and Conservation. 4:95-109.

Gillespie GR, Ahmad E, Elahan B, Evans A, Ancrenaz M, Goossens B, Scroggie MP. 2012. Conservation of amphibians in Borneo: Relative value of secondary tropical forest and non-forest habitats. Biological Conservation. 152:136-14.

Hocking DJ, Babbit KJ. 2014. Amphibian contributions to ecosystem services. Herpetological Conservation and Biology. 9(1):1-17.

Hutchinson, MN. 1993. Family scincidae. Fauna of Australia. 2:261-279.

Inger RF, Stuebing RB. 1997. A Field Guide to The Frogs of Borneo. Sabah: Natural History Publications. Irham M, Pungki L, Nur RI, Connie MS. 2012. Fauna Indonesia. Bogor: Masyarakat Zoologi Indonesia.

Iskandar DT, Erdelen WR. 2006. Conservation of amphibians and reptiles in Indonesia: Issues and problems. Amphibian and Reptile Conservation. 4(1):60-9.

Iskandar DT. 1998. Amfibi Jawa dan Bali LIPI Seri Panduan Lapangan. Bogor: Puslitbang LIPI.

Kendeigh SC. 1980. Ecology with Special Reference to Animal and Men. New Delhi: Prentice Hall of India Private limited.

Koh LP, Wilcove DS. 2008. Is palm oil agriculture really destroying tropical biodiversity?. Conservations Letter. 1:60-64.

Kurz DJ, Turner EC, Aryawan AA, Barkley HC, Caliman JP, Konopik O, Ps. S, Foster WA. 2016. Replanting reduces frog diversity in oil palm. Biotropica. 48:483-490.

Kusrini MD. 2009. Pedoman Penelitian dan Survei Amfibi di Alam. Bogor: Fakultas Kehutanan, Institut Pertanian Bogor.

Lehtinen RM dan Ramanamanjato JB. 2006. Effects of rainforest fragmentation and correlates of local extinction in a herpetofauna from Madagascar. Applied Herpetology. 3(2):95-110.

Lehtinen RM, Ramanamanjato JB, Raveloarison JG. 2003. Edge effects and extinction proneness in a herpetofauna from Madagascar. Biodiversity and Conservation. 12(7):1357-1370.

Luskin MS, Potts MD. 2011. Microclimate and habitat heterogeneity through the oil palm lifecycle. Basic and Applied Ecology. 12:540-551.

Mac Arthur RH. 1972. Geographycal Ecology: Patterns in Distribution of Spesies. New York: Harper and Row Publisher.

Magurran A. 1988. Ecological Diversity and Its Measurement. London: Croom Helmed Limited.

Mawazin, Atok S. 2013. Keanekaragaman dan komposisi jenis permudaan alam hutan rawa gambut bekas tebangan di Riau (species diversity and composition of logged over peat swamp forest in Riau). Forest Rehabilitation Journal. 1(1):59-73.

Meijaard E, Sheil D, Nasi R, Augeri D, Rosenbaum B, Iskandar D, Setyawati T, Lammertink M, Rachmatika I, Wong A, Soehartono T, Stanley S, Gunawan T, O'brien T. 2006. Hutan Pasca Pemanenan. Bogor: Center for International Forestry Research.

Mistar. 2008. Panduan Lapang Amfibi dan Reptil di Areal Mawas Propinsi Kalimantan Tengah (Catatan 
di Hutan Lindung Beratus). Kalimantan Tengah: BOS Foundation.

Muslim T. 2017. Herpetofauna community establishment on the micro habitat as a result of land mines fragmentation in East Kalimantan, Indonesia. Biodiversitas. 18(2):709-714.

Odum EP. 1971. Fundamentals of Ecology. Philadelphia: WB Saunders Company.

Santosa Y. 1995. Teknik Pengukuran Keanekaragaman Satwaliar. Bogor: Jurusan Konservasi Sumberdaya Hutan Fakultas Kehutanan-Institut Pertanian Bogor.

Septiawan H, Hariadi M, Thohari. 2014. Analisis Pengelolaan Lingkungan Pabrik kelapa Sawit Batu Ampar- PT. Smart Tbk. Dalam Implementasi Indonesian Sustainable Palm Oil. Jurnal Pengelolaan Sumber Daya Alam dan Lingkungan. 4(2):136-144.

Stuebbin RC dan Cohen NW. 1997. A Natural History of Amphibian. New Jersey: Princeton University Press.

Urbina-Cardona JN. 2008. Conservation of neotropical herpetofauna: research trends and challenges. Tropical Conservation Science. 1(4):359-375.

Vitt LJ, Caldwell JP. 2001. The effects of logging on reptiles and amphibians of tropical forests. In: Fimbel, R.A., Grajal, A., Robinson, J. (Eds.). The Cutting Edge: Conserving Wildlife in Logged Tropical Forests. New York: Columbia University Press.

Wanger TC, Iskandar DT, Motzke I., Brook BW, Sodhi NS, Clough Y, dan Tscharntke T. 2010. Effects of land-use change on community composition of tropical amphibians and reptiles in Sulawesi, Indonesia. Conservation Biology. 24: 795-802.

Yanuarefa MF, Gendut H, Joko U. 2012. Panduan Lapang Herpetofauna (Amfibi dan Reptil) Taman Nasional Alas Purwo. Banyuwangi: Balai Taman Nasional Alas Purwo. 